\title{
Effects of Fasting on Insulin Binding, Glucose Transport, and Glucose Oxidation in Isolated Rat Adipocytes
}

\author{
RELATIONSHIPS BETWEEN INSULIN RECEPTORS \\ AND INSULIN ACTION \\ JERROLD M. OLEFSKY \\ From the Division of Endocrinology and Metabolism, Stanford University School of Medicine, \\ Stanford, California 94305, and the Palo Alto Veterans Administration Hospital, \\ Palo Alto, California 94304
}

A в S T R A C T Insulin binding, glucose transport, and glucose oxidation were studied in isolated adipocytes obtained from fasting rats. Fasting led to an increase in the overall binding affinity for insulin, while the number of receptor sites per cell remained constant. Glucose oxidation was markedly attenuated during fasting. Basal rates of oxidation decreased by about $50 \%$, while insulin-stimulated rates decreased 6 to 10-fold. Glucose transport was assessed by measuring initial uptake rates of 2-deoxy-glucose. Fasting led to a 40-50\% decrease in the apparent maximal transport capacity $\left(\mathrm{V}_{\max }\right)$ of 2-deoxy-glucose uptake with no change in apparent $K_{m}$. A progressive decrease in basal and insulin-stimulated rates of 2-deoxy-glucose uptake was seen from $24-72 \mathrm{~h}$ of starvation and a significant correlation $(r=0.85, P<0.001)$ existed between basal and maximal insulin-stimulated uptake rates in individual animals. When 2-deoxy-glucose uptake was plotted as a function of insulin bound, due to the decrease in maximal uptake capacity, cells from fasting animals took up less hexose for any amount of insulin bound. When the insulin bound was plotted as a function of the percent insulin effect on uptake, control cells and cells from 24-hfasted rats gave comparable results, while cells from 48- and 72-h-fasted animals still took up less hexose for any amount of bound insulin. The effects of fasting on 3-O-methyl glucose uptake were comparable to the 2-deoxy-glucose data. In conclusion: $(a)$ insulin binding is increased during fasting due to an increased

Dr. Olefsky is a Clinical Investigator with the Veterans Administration Hospital.

Received for publication 20 May 1976 and in revised form 27 August 1976. overall binding affinity with no change in receptor number; $(b)$ glucose oxidation is severely impaired during fasting; (c) 2-deoxy-glucose uptake decreases with fasting due to a decrease in maximal transport capacity $\left(V_{\max }\right)$ with no change in $K_{m} ;(d)$ the decrease in glucose oxidation is much greater than the decrease in glucose transport, indicating impaired intracellular oxidative metabolism; and $(e)$ coupling between insulin receptors and the glucose transport system is normal after $24 \mathrm{~h}$ of fasting but is impaired at 48 and $72 \mathrm{~h}$.

\section{INTRODUCTION}

Fasting has profound effects on in vivo glucose metal)olism, resulting in a state of glucose intolerance often called "starvation diabetes" (1). This state is characterized by attenuated insulin action (2), and can thus be considered as a state of insulin resistance. At the cellular level, tissues from fasting animals display decreased basal rates of glucose oxidation and a marked decrease in the ability of insulin to promote glucose conversion to $\mathrm{CO}_{2}$ (3). At first glance the above in vivo and in vitro observations appear consistent. However, glucose oxidation is a relatively distal effect of insulin action, and to understand more fully the alterations of insulin action at the cellular level in fasting, additional information is necessary concerning other (and earlier) aspects of glucose metabolism. To complicate the picture further, it has been demonstrated that fasting leads to an increase in insulin binding to insulin target tissues $(4,5)$, and since binding to receptors represents the initial step of insulin's action, one might anticipate an increase rather than a decrease in insulin's effects on cells 
TABLE I

Characteristics of Experimental Animals

\begin{tabular}{|c|c|c|c|c|c|c|}
\hline \multirow[b]{2}{*}{ Animals } & \multirow[b]{2}{*}{ Number } & \multicolumn{2}{|c|}{ Weight } & \multirow{2}{*}{$\begin{array}{l}\text { Fat cell } \\
\text { volume }\end{array}$} & \multirow{2}{*}{$\begin{array}{l}\text { Fasting } \\
\text { insulin }\end{array}$} & \multirow{2}{*}{$\begin{array}{l}\text { Fasting } \\
\text { glucose }\end{array}$} \\
\hline & & Before & After & & & \\
\hline & & \multicolumn{2}{|c|}{$g$} & $p l$ & $\mu U / m l$ & $m g / 100 \mathrm{ml}$ \\
\hline Controls & 45 & - & $184 \pm 5$ & $73 \pm 3$ & $30 \pm 4$ & $140 \pm 5$ \\
\hline 24-h fast & 17 & $194 \pm 3$ & $175 \pm 3$ & $72 \pm 6$ & $7 \pm 1$ & $106 \pm 3$ \\
\hline 48-h fast & 22 & $198 \pm 2$ & $168 \pm 4$ & $64 \pm 4$ & $11 \pm 4$ & $112 \pm 4$ \\
\hline 72-h fast & 27 & $198 \pm 3$ & $154 \pm 3$ & $50 \pm 3$ & $11 \pm 3$ & $117 \pm 4$ \\
\hline Weight reduction & 7 & $194 \pm 3$ & $184 \pm 2$ & $69 \pm 4$ & $3 \pm 3$ & $134 \pm 7$ \\
\hline
\end{tabular}

during fasting. However, the relationship between changes in insulin receptors and changes in insulin action is complex. For example, maximal insulin stimulation of adipocyte glucose metabolism occurs when only a small fraction of the cell's insulin receptors are occupied (6-8), and, thus, the functional sequela of a change in the ability of cells to bind insulin would be a corresponding change in insulin action only at insulin levels that occupy less than the number of receptors required for a maximal effect, with unchanged responses to maximally effective insulin levels. Thus, theoretically, a decrease in insulin binding should lead to a rightward shift in the insulin dose-response curve (9), and an increase in insulin binding should lead to a leftward shift in the curve. Obviously, the above ideas will only be accurate if the aspect of insulin action measured is not itself independently altered by the perturbation that leads to a change in insulin binding. Therefore, in an attempt to further delineate the effects of fasting on adipocyte insulin receptors and glucose metabolism and especially to interrelate insulin binding and insulin action, we have studied insulin binding, glucose transport, and glucose oxidation is isolated adipocytes prepared from rats fasted for varying lengths of time.

\section{METHODS}

Materials. Porcine monocomponent insulin was generously supplied by Dr. Ronald Chance of the Eli Lilly and Company (Indianapolis, Ind.). $\mathrm{Na}\left[{ }^{125} \mathrm{I}\right]$ was purchased from New England Nuclear (Boston, Mass.), bovine serum albumin (fraction V) from Armour Pharmaceutical Co. (Phoenix, Ariz.), collagenase from Worthington Biochemical Corp. (Freehold, N.J.), and $\left[1-{ }^{14} \mathrm{C}\right]$ glucose, 2-deoxy- $\left[1-{ }^{14} \mathrm{C}\right] \mathrm{glu}$ cose, 3-O-methyl- $\left[1-{ }^{14} \mathrm{C}\right]$ glucose, and $\left[{ }^{14} \mathrm{C}\right]$ inulin from $\mathrm{New}$ England Nuclear Co.

Animals. Male Sprague-Dawley rats were used for all experiments. Control animals weighed between 170 and $190 \mathrm{~g}$ and were fed ad lib until the morning of all studies. 24-, 48-, and 72-h-fasted animals were deprived of food for the indicated intervals beginning at $8 \mathrm{a} . \mathrm{m}$. of day 0 . Table I presents the mean $( \pm \mathrm{SE})$ plasma glucose and insulin values, body weight, and adipocyte sizes for each group of animals.

Preparation of isolated adipocytes. All studies were begun between 8-9 a.m. Animals were stunned by a blow to the head and decapitated, and epididymal fat pads were removed. Isolated fat cells were prepared by shaking at $37^{\circ} \mathrm{C}$ for $60 \mathrm{~min}$ in Krebs-Ringer bicarbonate buffer containing collagenase $(3 \mathrm{mg} / \mathrm{ml})$ and albumin $(40 \mathrm{mg} / \mathrm{ml})$, by the method of Rodbell (10). Cells were then filtered through $250-\mu \mathrm{m}$ nylon mesh, centrifuged at $400 \mathrm{rpm}$ for $4 \mathrm{~min}$, and washed twice in buffer (4). Adipocyte counts were performed according to a modification of method III of Hirsch and Gallian (11), in which the cells were fixed in $2 \%$ osmium tetroxide in $0.05 \mathrm{M}$ collidine buffer (made isotonic with saline) for $24 \mathrm{~h}$ at $37^{\circ} \mathrm{C}$ and then taken up in a known volume of $0.154 \mathrm{M} \mathrm{NaCl}$ for counting with a Celluscope Model $112 \mathrm{H}$ particle counter with a $400-\mu \mathrm{m}$ aperture (Particle Data, Inc., Elmhurst, Ill.). Adipocyte size was determined with a calibrated microscope by the method of Di Girolamo (12).

Iodination of insulin. ${ }^{125} \mathrm{I}$-insulin was prepared at a specific activity of $100-150 \mu \mathrm{Ci} / \mu \mathrm{g}$ according to Freychet et al's. modification (13) of the method of Hunter and Greenwood (14), as previously described (15).

Binding studies. Isolated fat cells were suspended in a buffer containing $35 \mathrm{mM}$ Tris, $120 \mathrm{mM} \mathrm{NaCl}, 1.2 \mathrm{mM}$ $\mathrm{MgSO}_{4}, 2.5 \mathrm{mM} \mathrm{KCl}, 10 \mathrm{mM}$ glucose, $1 \mathrm{mM}$ EDTA, $1 \%$ bovine serum albumin (16), $\mathrm{pH} 7.6$, and incubated with ${ }^{125} \mathrm{I}$-insulin and unlabeled insulin in plastic flasks in a $24^{\circ} \mathrm{C}$ shaking water bath as previously described $(4,17,18)$. Optimal steady-state binding conditions are achieved at $24^{\circ} \mathrm{C}$ after $45 \mathrm{~min}$ of incubation $(4,18)$. The incubations were terminated as described by Gammeltoft and Gliemann (8), by removing $200-\mu$ l portions from the cell suspension and rapidly centrifuging the cells in plastic microtubes to which $100 \mu \mathrm{l}$ of dinonyl phthalate oil had been added. Dinonyl phthalate has a specific gravity intermediate between buffer and cells, and therefore, after centrifugation, three layers result: cells on top, oil in the middle, and buffer on the bottom. The cells were then removed and the radioactivity was determined. All studies were done in triplicate.

Glucose oxidation studies. The ability of adipocytes to oxidize glucose was determined according to the method of Rodbell (10). Unless otherwise stated, adipocytes were incubated at $37^{\circ} \mathrm{C}$ with $\left[1{ }^{14} \mathrm{C}\right]$ glucose at a total glucose concentration of $2 \mathrm{mM}$ in Krebs-Ringer bicarbonate buffer, $\mathrm{pH} 7.4$, containing bovine serum albumin $(40 \mathrm{mg} / \mathrm{ml})$. After $1 \mathrm{~h}$ of incubation, the generated ${ }^{14} \mathrm{CO}_{2}$ was collected and counted in a liquid scintillation counter.

Glucose transport studies. Transport studies used the same cell centrifugation technique as the binding studies and the details of this method have been previously described $(6,9)$. Unless otherwise stated, isolated adipocytes were incubated with 2-deoxy-[1-14C]-D-glucose (sp act $2 \mathrm{mCi} / \mathrm{mM}$ ) at a concentration of $0.125 \mathrm{mM}$ in Krebs-Ringer bicarbonate, $\mathrm{pH} 7.4$, containing bovine serum albumin $(10 \mathrm{mg} / \mathrm{ml})$ at $24^{\circ} \mathrm{C}$. This assay measures the total uptake of the radio- 


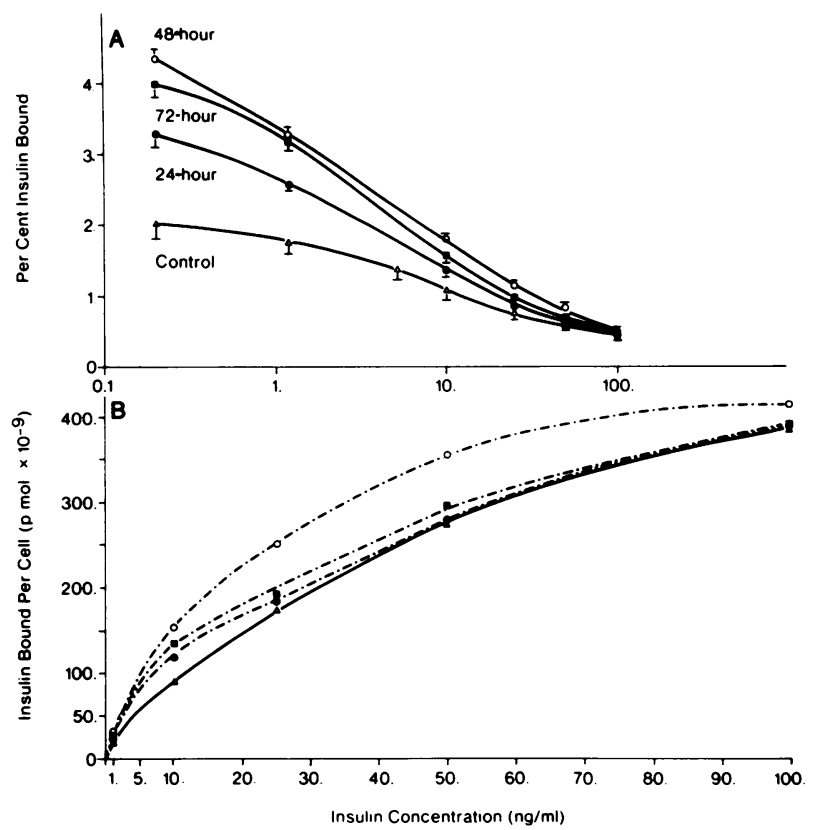

Figure 1 Ability of adipocytes from control $(\triangle)$, 24-h (O), 48-h $(\bigcirc)$, and $72-\mathrm{h}(\square)$ fasted rats to specifically bind ${ }^{125}$ I-insulin. Data represent the mean $( \pm \mathrm{SE})$ of 12 (control) and 7 (for each fasting group) separate experiments performed on different batches of cells prepared on different days. Cells were incubated for $45 \mathrm{~min}$ at $24^{\circ} \mathrm{C}$ with $33 \mathrm{pM}$ ${ }^{125} \mathrm{I}$-insulin $(0.2 \mathrm{ng} / \mathrm{ml})$ plus unlabeled insulin to give the indicated total insulin concentrations. All data were corrected for nonspecific binding by subtracting the amount of radioactivity remaining bound at an insulin concentration of $200 \mu \mathrm{g} / \mathrm{ml}$ from the amount of radioactivity in the cell pellet at all other insulin concentrations $(4,5,23)$. A. Relationship between the percent insulin bound by $2 \times 10^{5}$ cells (vertical axis) and insulin concentration (horizontal axis). $B$. The relationship between the amount of insulin bound (pmoles $\times 10^{-9} /$ cell) and insulin concentration (horizontal axis).

labeled 2-deoxy-glucose and is based on the principle that while 2-deoxy-glucose is transported and phosphorylated by the same processes as D-glucose, it cannot be further metabolized (19). The assay was terminated at the end of $3 \mathrm{~min}$ by transferring $200-\mu \mathrm{l}$ aliquots from the assay mixture to plastic microtubes containing $100 \mu \mathrm{l}$ dinonyl phthalate oil. The tubes were centrifuged for $30 \mathrm{~s}$ in a Beckman microfuge (Beckman Instruments, Inc., Spinco Div., Palo Alto, Calif.), and the assay was considered terminated when centrifugation began. In experiments in which the stimulatory effect of insulin on uptake was measured, the cells were preincubated with insulin for $45 \mathrm{~min}$ at $24^{\circ} \mathrm{C}$. The amount of sugar trapped in the extracellular water space of the cell layers was determined with $\left[{ }^{14} \mathrm{C}\right]$ inulin by the method of Gliemann et al. (20). Extracellular water space was measured in each experiment, and all data of sugar uptake were corrected for this factor. The percent of the total amount of sugar available that was trapped in the extracellular water space was a linear function of cell concentration, and averaged $0.033 \pm 0.001 \%$ at a concentration of $2 \times 10^{5} \mathrm{cells} / \mathrm{ml}$. The amount of trapped sugar ranged from 2 to $10 \%$ of the total sugar uptake, depending on the conditions of incubation.

Analytical methods. Plasma glucose was measured by the glucose oxidase method with a Beckman glucose analyzer
(Beckman Instruments, Inc., Fullerton, Calif.), and plasma insulin level was measured by the method of Desbuquois and Aurbach (21).

\section{RESULTS}

Insulin binding studies. Fig. 1 summarizes the insulin binding studies performed on isolated adipocytes from the fasted and control animals. Fasting results in an increase in the ability of adipocytes to bind insulin and this effect is pronounced as early as $24 \mathrm{~h}$. Binding continues to increase between 24 and $48 \mathrm{~h}$, but no further increase occurs between 48 and $72 \mathrm{~h}$, and this is similar to previous data that we reported in fasted obese animals (4). The data in Fig. 1 have been corrected for nonspecific binding, and thus, represent specific insulin binding. At 0.2 $\mathrm{ng} / \mathrm{ml}{ }^{125} \mathrm{I}$-insulin, nonspecific binding averaged 0.52 , $0.41,0.50$, and $0.45 \%$ of the total available ${ }^{125} \mathrm{I}$-insulin and $8.1,4.5,2.9$, and $4.0 \%$ of the total amount of insulin bound to cells from control, 24-, 72-, and $48 \mathrm{~h}-$ fasted animals, respectively. In Fig. 1A the decrease in the percent insulin bound as total insulin concentra-

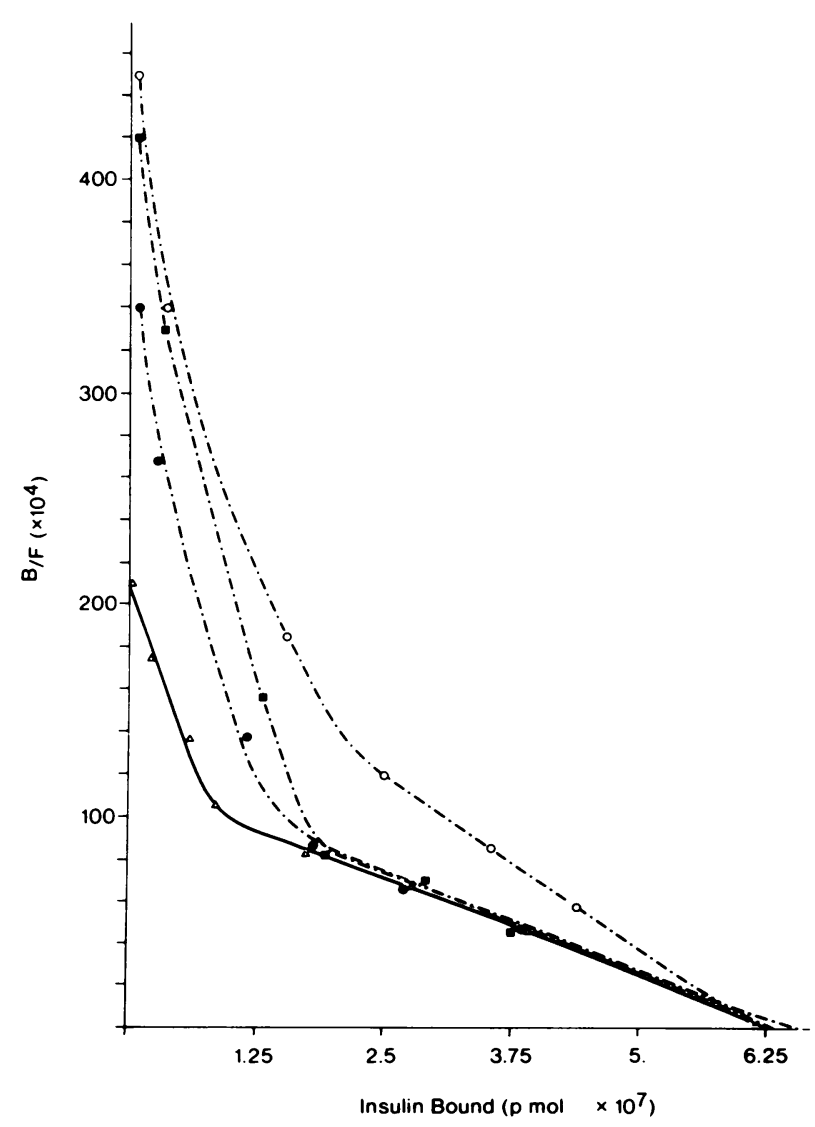

FIGURE 2 Scatchard plots $(22)$ of the insulin binding data for control $(\triangle), 24-\mathrm{h}(\bullet), 48-\mathrm{h}(\bigcirc)$, and $72-\mathrm{h}(\boldsymbol{\square})$ fasted rats. The ratio of bound to free hormone $(B / F)$ is on the ordinate, and bound hormone is on the abscissa. 
tion increases is greater for the fasting groups, and the curves converge at the higher insulin concentrations. This suggests that the cells from the fasting animals have a higher overall affinity for insulin than the cells from controls, but have the same number of receptors. This is also seen in Fig. 1B, which shows that at the lower (and physiologic) insulin concentrations, cells from fasting rats bind more insulin, whereas at the highest insulin concentration the amount bound is comparable for all four groups. This point is made clearer by examining the Scatchard plots (22) of the binding data, as seen in Fig. 2. Although it is difficult to calculate the exact binding affinity from curvilinear Scatchard plots $(23,24)$, the generally steeper slopes of the curves from the fasting animals indicate that the overall binding affinity is greater than for control cells. Furthermore, the horizontal intercepts of the terminal slopes of these plots represent the total number of receptor sites present, and therefore, the data in Fig. 2 demonstrate that all four groups of cells have approximately the same number of receptor sites per cell. This indicates that the increased insulin binding seen in Fig. 1 (at the insulin concentrations $<100 \mathrm{ng} / \mathrm{ml}$ ) is due to increased affinity of the receptor for insulin.

However, others have shown that cells from fasted animals are relatively insensitive to insulin and, as a first approximation, this does not seem consistent with increased insulin binding to these cells. Therefore, the following series of studies were designed to investigate the effects of fasting on glucose

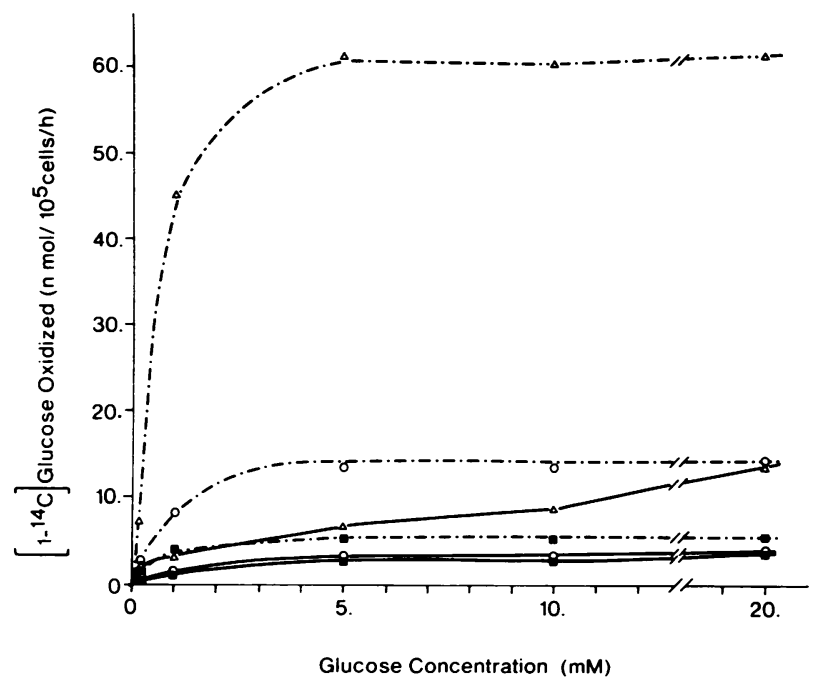

FIGURE 3 Effect of glucose concentration on glucose oxidation by cells from control $(\triangle), 48-h(O)$, and $72-h(\square)$ fasted rats. Cells were incubated with increasing glucose concentrations in the absence $(-)$ and presence $(-\cdots)$ of $25 \mathrm{ng} / \mathrm{ml}$ insulin. Data represent the mean of five separate experiments for each group.
TABLE II

Insulin-Mediated Percent Increase in Glucose Oxidation

\begin{tabular}{lrrrr}
\hline & \multicolumn{5}{c}{ Glucose concentration } \\
\cline { 2 - 5 } & $1 . \mathrm{mM}$ & $5 . \mathrm{mM}$ & $10 . \mathrm{mM}$ & $20 . \mathrm{mM}$ \\
\hline & & \multicolumn{4}{c}{} \\
Control & 1,666 & 938 & 717 & 460 \\
48 -h fast & 567 & 487 & 475 & 337 \\
72 -h fast & 177 & 157 & 158 & 115 \\
\hline
\end{tabular}

Calculations are derived from the data in Fig. 3 and represent the rate of glucose oxidation in the presence of a maximally effective insulin level $(25 \mathrm{ng} / \mathrm{ml})$ divided by the rate of oxidation in the basal state $\times 100$.

metabolism and the relationship between insulin binding and insulin's biologic effects in adipocytes from control and fasting animals.

Glucose oxidation studies. Glucose oxidation was studied at increasing media glucose concentrations in the presence and absence of maximally effective insulin levels $(25 \mathrm{ng} / \mathrm{ml})$ with cells from control, 48-, and 72-h-fasted animals. The results are seen in Fig. 3. After 2 days of fasting, basal rates (absence of insulin) of glucose oxidation are significantly decreased, compared to controls, at all glucose concentrations. In the presence of insulin, 2 days of fasting also leads to a marked decrease in maximally insulin-stimulated rates of oxidation at all glucose concentrations. Since both basal and maximal-insulin stimulated rates of glucose oxidation decrease, it is of interest to examine the percent increase in oxidation due to insulin. If the data are analyzed as percent increase, differences between control and 2-day-fasted animals are still apparent, although they are not as marked (Table II). After 3 days of fasting, no further decrease in basal glucose oxidation occurs, but a further marked attenuation of insulin-stimulated oxidation is seen. Since basal glucose oxidation does not decline further, the decrease in insulin response is marked even when the data are analyzed as percent increase in glucose oxidation due to insulin (Table II). However, this does not necessarily mean that the cells have become resistant to insulin, since the data indicate that the major effect of fasting on glucose oxidation is to markedly inhibit the intrinsic capacity of the cells to metabolize glucose. Thus, cellular insulin resistance should be subdivided into situations in which receptor function is altered or in which effector function is altered, and the data in Fig. 3 point to a defect in the effector systems of glucose metabolism.

To examine more fully the insulin responsiveness of adipocytes from fasted rats, glucose oxidation was studied at a single glucose concentration $(2 \mathrm{mM})$ but a variety of insulin levels. These insulin dose-response 
curves are seen in Fig. 4. Again, one can see that absolute rates of glucose oxidation are decreased in the basal state, and at all insulin concentrations with fasting. Furthermore, since maximally effective insulin levels do not overcome this defect in glucose oxidation, the lesion is in the effector system.

However, increases in glucose oxidation represent a rather distal effect of insulin and are probably mediated via insulin's separate effects on glucose transport as well as intracellular glucose metabolism (6). Therefore, to understand further the effects of fasting on glucose metabolism, and to define better the relationship between insulin receptors and insulin action, glucose transport was studied in cells from fasting and control animals.

Glucose transport studies. 2-Deoxy glucose was used to assess glucose transport $(6,9,25-28)$ at increasing 2-deoxy glucose concentrations with cells from control and 48-h-fasted rats. Incubations were performed in the presence and absence of maximally effective insulin levels $(25 \mathrm{ng} / \mathrm{ml})$, and the results are seen in Fig. 5. Fasting leads to a striking decrease in basal rates of 2-deoxy-glucose uptake, and this decrease is comparable at all hexose concentrations. Insulin does not overcome this decrease, and similar differences exist at a maximally effective insulin level. The shape of all four curves in Fig. 5 suggests two uptake components: a saturable component seen at 2-deoxy-glucose concentrations less than $5 \mathrm{mM}$, and a nonsaturable, linear component seen at higher sugar concentrations. This phenomenon has been previously described for 2-deoxy-glucose uptake by other cell systems (25-28), and we have reported similar

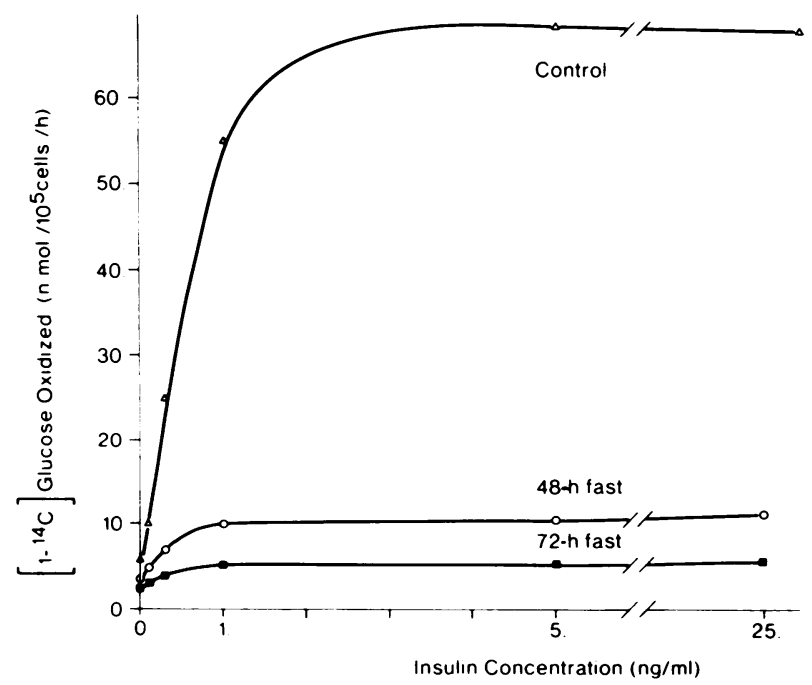

FIGURE 4 Effect of insulin concentration on glucose oxidation by cells from control $(\triangle), 48-h(O)$, and $72-h(\square)$ fasted rats. Data represent the mean of 12,6 , and 7 separate experiments, respectively. Glucose concentration was $2 \mathrm{mM}$.

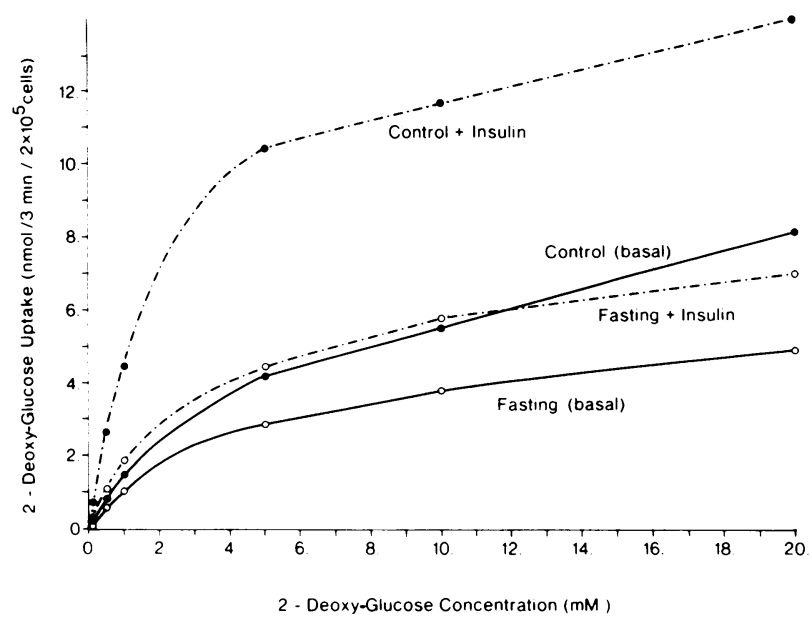

Figure 5 Effect of substrate concentration on 2-deoxyglucose uptake by cells from control (O), and 48-h (O) fasted rats in the basal ( $\_$) and insulin-stimulated state $(-\cdots)$. Cells were preincubated with or without insulin for $45 \mathrm{~min}$ at $24^{\circ} \mathrm{C}$. Uptake was then measured at the end of a 3-min incubation with 2-deoxy-glucose at the indicated concentrations. At 2-deoxy-glucose concentrations over $5 \mathrm{mM}$, the slopes of the curves represent simple inward diffusion of the sugar into the cells $(6,9,25-28)$, and the data can be corrected for this linear diffusion component by subtracting the contribution of this linear process from the absolute value $(6,9,25-28)$. Data represent the mean of six separate experiments for each group.

observations in isolated adipocytes $(6,9)$. It is likely that the nonsaturable component represents simple inward diffusion of labeled hexose (6, 9, 25-28), and the data can be corrected for this diffusion component by subtracting the contribution of this linear process: ${ }^{1}$ When these corrected data are submitted to Lineweaver-Burk analysis, apparent $K_{m}$ and $V_{\max }$ values can be calculated. With this approach (Table III), the apparent $K_{m}$ of 2-deoxy-glucose uptake is comparable in both groups of cells in the presence or absence of insulin $(2.5-3.0 \mathrm{mM})$. On the other hand, the apparent $V_{\max }$ values are lower in fasting in both the basal $\left(4.8\right.$ vs. $8.3 \mathrm{nmol} / \mathrm{min}$ per $10^{6}$ cells) and insulin-stimulated (12.0 vs. $23.7 \mathrm{nmol} / \mathrm{min}$ per $10^{6}$ cells) state. Thus, fasting appears to decrease the intrinsic activity of the adipocyte glucose transport system, and insulin does not overcome this defect. Furthermore, other agents that stimulate glucose transport (cysteine and spermidine) cannot stimulate 2-deoxy-glucose uptake to the same absolute rate in cells from fasting animals compared to controls ${ }^{2}$ and thus, the observed decreases in $V_{\max }$ relate to de-

${ }^{1}$ The slope of the diffusion process is less for cells from fasting animals than for control cells, and it is possible that this could be related to changes in membrane permeability as a result of the decrease in cell volume during fasting.

${ }^{2}$ Unpublished observations. 
creases in transport system capacity and are not unique to the insulin-stimulatory mechanism.

The effects of fasting on glucose transport were always proportional in the basal and maximal insulinstimulated state, and this is emphasized in Fig. 6. In this figure, 2-deoxy-glucose uptake was assessed at very low hexose concentrations $(0.125 \mathrm{mM})$ in the absence (basal) and presence of maximally effective insulin levels $(25 \mathrm{ng} / \mathrm{ml})$. Animals were fasted for 24 , 48 , and $72 \mathrm{~h}$ and all of the individual data are plotted. A highly significant positive correlation (Fig. 6, $r=0.85, P<0.001$ ) exists between basal and maximal insulin-stimulated glucose uptake, demonstrating that under these circumstances the ability of insulin to promote 2-deoxy-glucose uptake is proportional to the rate of basal uptake. Furthermore, if weight loss is used as a measure of negative caloric balance, similar and highly significant correlations exist between the loss of weight during fasting and the decrease in basal $(r=0.72, P<0.001)$ and insulin-stimulated $(r=0.78, P<0.001)$ rates of 2-deoxy-glucose uptake.

Evaluation of the insulin responsiveness of these cells is further complicated by the fact that maximal insulin stimulation of glucose metabolism occurs when only a small fraction of adipocyte insulin receptors are occupied. Thus, the relationship between the receptors for insulin and the effector systems are best studied at insulin concentrations that occupy less than the number of receptors needed for maximal responses to insulin and thus, elicit submaximal insulin effects. These data are seen in Fig. 7A, which summarizes the insulin 2-deoxy-glucose uptake response curves for control, 24-, 48-, and 72-h-fasted rats. These data demonstrate that 2-deoxy-glucose uptake is decreased at all insulin levels, and that this decrease is progressive with the degree of fasting. However, the decreases in absolute rates of 2-deoxyglucose uptake are due to decreases in the capacity $\left(V_{\max }\right)$ of the glucose transport system, and are not necessarily related to a defect in the ability of insulin to stimulate this process. Therefore, since the basal rates of uptake also decrease with fasting, and since the basal and insulin-stimulated uptake rates are pro-

TABLE III

Apparent $\mathrm{K}_{\mathrm{m}}$ and $\mathrm{V}_{\max }$ Values for 2-Deoxy Glucose Uptake

\begin{tabular}{ccc} 
& $K_{m}$ & $\mathrm{~V}_{\max }$ \\
\hline & $m M$ & $n$ mol $/ \min / 10^{6}$ cells \\
Control & & \\
Basal & 2.5 & 8.3 \\
Insulin & 2.8 & 23.7 \\
48-h fast & & \\
Basal & 2.8 & 4.8 \\
Insulin & 3.0 & 12.0 \\
\hline
\end{tabular}

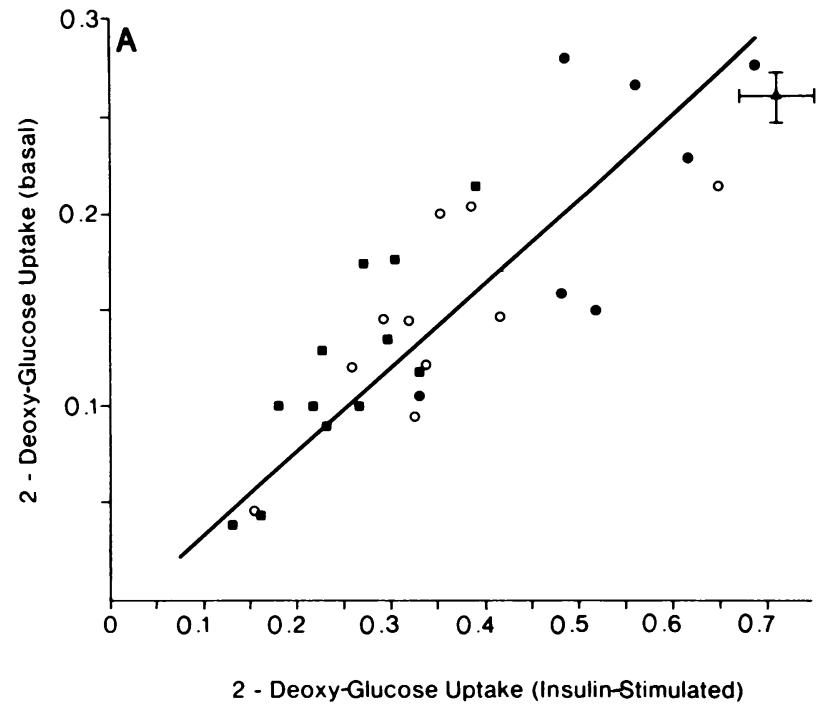

FIGURE 6 Relationship between basal and maximal insulinstimulated rates of 2-deoxy-glucose uptake (in nanomoles/ $3 \mathrm{~min} / 2 \times 10^{5}$ cells) for each individual rat fasted for $24(0)$, $48(\mathrm{O})$ and $72(\square) \mathrm{h}$. Solid triangle represents the mean $\pm \mathrm{SE}$ for control cells. $r=0.85 ; P<0.001$.

portional (Fig. 6A), to compare the shapes of the insulin dose response curves, the data in Fig. 7A can be analyzed as percent increases above basal. With this analysis (7B), the dose-response curves are quite comparable for the control, 48-h, and 72-h-fasted animals, but the data from the 24-h-fasted animals demonstrate a shift to the left. When the data are plotted as a percent of the maximal insulin effect (7C), similar findings are noted.

The glucose analogue 2-deoxy-glucose is transported and phosphorylated (but not further metabolized) and we have previously shown that in white adipocytes, under these experimental conditions, transport, not phosphorylation, is the rate-determining step $(6,9)$. However, to further document this, 3-O-methyl-glucose uptake studies were performed in the control and fasting (72-h) states and the results of these experiments are seen in Fig. 8. Since this glucose analogue is not phosphorylated, its uptake is solely a measure of transport $(26,29)$, and, as can be seen, the results with 3-O-methyl-glucose are entirely comparable to those with 2-deoxy-glucose. However, because 3-O-methyl-glucose is not phosphorylated (and consequently trapped inside the cell) equilibrium is rapidly reached due to significant efflux of the sugar. Uptake is nonlinear at very early time points (20-45 s [6]) and, thus, with these techniques, 2-deoxy-glucose allows more accurate assessments of glucose transport than 3-O-methyl-glucose, especially at higher substrate concentrations.

Relationship between insulin binding and glucose metabolism. The data thus far indicate that fasting 

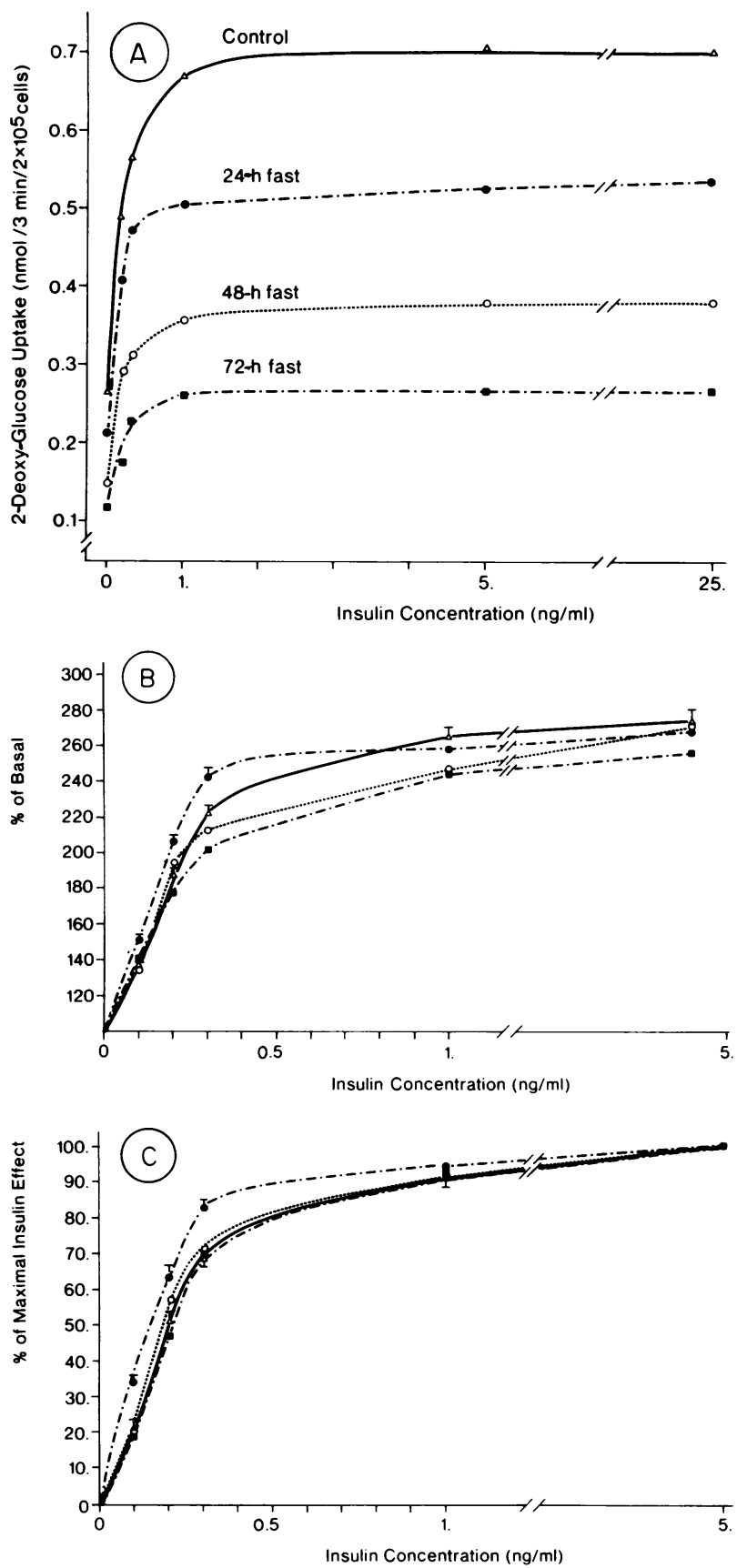

Figure 7A Effect of insulin concentration on 2-deoxyglucose uptake by cells from control $(\triangle), 24-\mathrm{h}(\bullet), 48-\mathrm{h}$ $(O)$, and 72-h ( $\square)$ fasted animals. Data represent the mean of $15,7,10$, and 12 separate experiments, respectively. B. The 2-deoxy-glucose uptake data are plotted as percent increase above basal (total uptake rate $\div$ basal uptake rate). Brackets represent $\pm S E$ and data from 24 -h-fasted rats are significantly different from control at all insulin concentrations under $1 \mathrm{ng} / \mathrm{ml}$. C. The uptake data plotted as percent of the maximal insulin effect. This is calculated by dividing the increment in 2-deoxy-glucose uptake (absolute value - basal) at the indicated insulin concentration by the maximum increment in uptake (at $25 \mathrm{ng} / \mathrm{ml}$ ) (9). Brackets represent $\pm \mathrm{SE}$, and data from 24 -h-fasted rats are significantly different from control at all insulin concentrations under $1 \mathrm{ng} / \mathrm{ml}$.

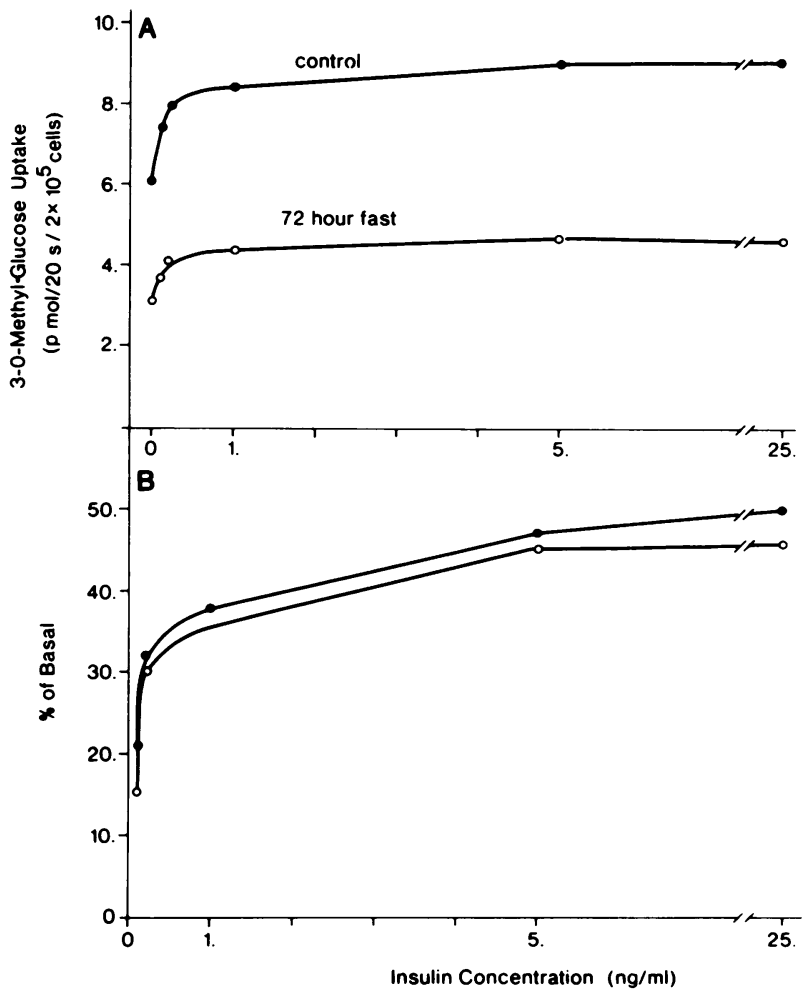

FIGURE 8 3-O-methyl-glucose uptake by cells from control (O) and 72-h $(O)$ fasted rats. Cells were preincubated with or without insulin for $45 \mathrm{~min}$ at $24^{\circ} \mathrm{C}$. Uptake is then measured $30 \mathrm{~s}$ after the addition of 3-O-methyl-glucose $(20 \mu \mathrm{M})$. Data represent the mean of three separate experiments for each group. In $\mathrm{A}$, absolute rates of uptake are plotted as a function of insulin concentrations, and in B uptake is calculated as percent increase above basal.

leads to an increase in insulin binding, as well as a decrease in the ability of adipocytes to transport and metabolize glucose. Since insulin biading increases while the effector system activity dcirises, the relationship between receptors and effectior systems does not allow a totally unambiguous analysis. The quantitative relationship between the amount of insulin bound and 2-deoxyglucose uptake is seen in Fig. 9. The data in Fig. 9A show that adipocytes from fasted animals must bind more insulin to achieve a given insulin effect on 2-deoxy-glucose uptake as compared to control cells, but that due to the decrease in the capacity of the glucose transport system, the absolute magnitude of this effect is less than for control cells. In this sense, coupling between occupied insulin receptors and the glucose transport system is altered by fasting. However, since the absolute capacity of the transport system is decreased in fasting (decreased $V_{\text {max }}$ ), insulin (or any other stimulus) will be unable to increase uptake to levels seen in control cells and this would be unrelated to the interaction between occupied insulin receptors and glucose transport units. In Fig. 9B the decrease in transport capacity is taken into account, and the 
A

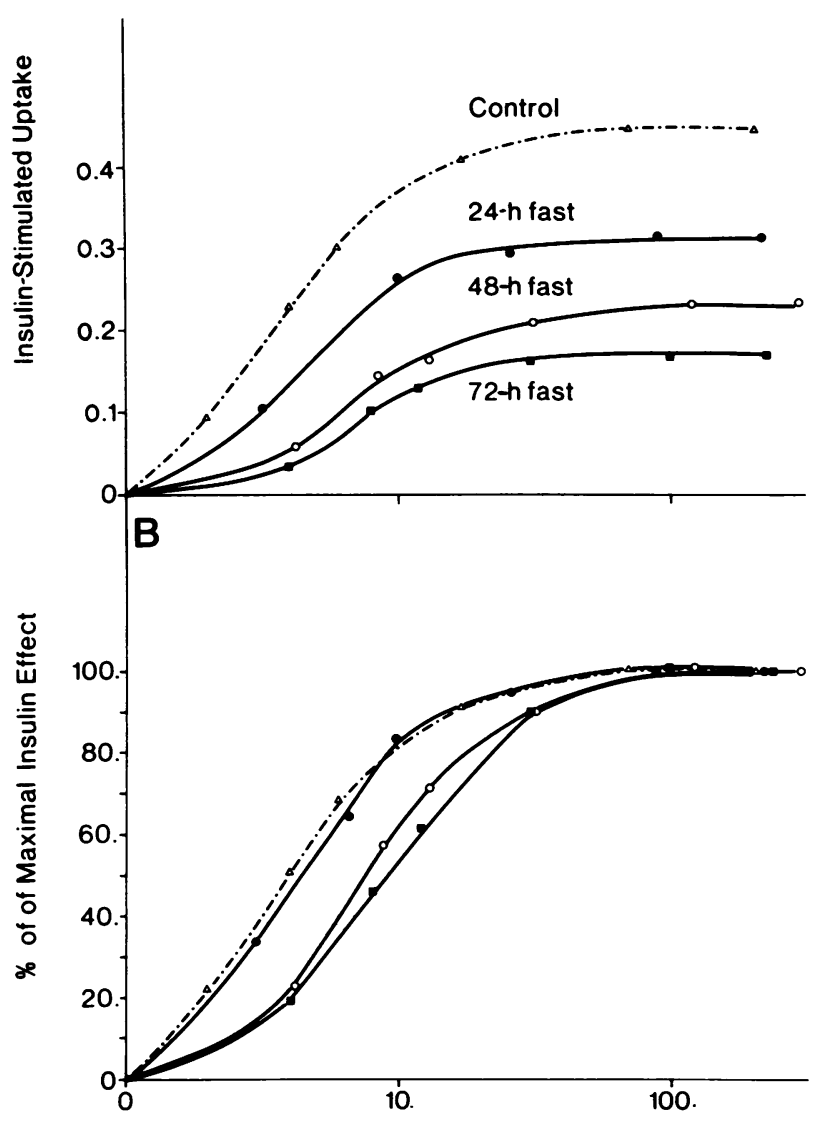

Amount of Insulin Bound (pg/2×105cells)

FIgURE 9 Relationship between the amount of insulin bound and 2-deoxy-glucose uptake (in nanomoles $/ 3 \mathrm{~min} / 2 \times 10^{5}$ cells, ordinate) for cells from control $(\triangle), 24-\mathrm{h}(\Theta), 48-\mathrm{h}(O)$, and 72 -h $(\boldsymbol{\square})$ fasted rats. In $A$ the uptake data are plotted as absolute values and in $\mathbf{B}$ the data are plotted as percent of the maximal insulin effect (see legend to Fig. 7 for details).

data are analyzed as percent of the maximal insulin effect. $^{3}$ It can be seen that cells from control and 24-hfasted rats must bind the same amount of insulin to achieve the same percent insulin effect, and the amount bound at the maximal insulin effect represents a fractional receptor saturation of $10-14 \%$. This is a reflection of the left shift in the data from the 24-hfasted rats as seen in Fig. $7 \mathrm{~B}$ and $\mathrm{C}$. On the other hand, cells from the 48- and 72-h-fasted animals must bind about twice as much insulin as control cells to achieve the same percent insulin effect (note log scale on abscissa), while the amount bound at the maximal insulin effect represents a fractional receptor saturation of 14-18\%. At higher insulin concentrations (>100

${ }^{3}$ This analysis would show the same relationships if the data were calculated as percent increase above basal (see Fig. 7B)
TABLE IV

Number of Insulin Molecules Bound Per Cell to Achieve Half-Maximal Stimulation of 2-Deoxy-Glucose Uptake

\begin{tabular}{lcr}
\hline & Half-maximal & Change \\
\hline & & $\%$ \\
Control & 2,050 & - \\
24-h fast & 2,152 & 5 \\
48-h fast & 3,843 & 87 \\
72-h fast & 4,346 & 112 \\
\hline
\end{tabular}

$\mathrm{ng} / \mathrm{ml}$ ) all groups of cells bind the same amount of insulin, but maximal insulin action occurs when only $10-18 \%$ of all available receptors are occupied (insulin concentrations $\simeq 5 \mathrm{ng} / \mathrm{ml}$ ) and at these low insulin concentrations, control cells bind less insulin than cells from fasting animals (Fig. 1). Thus, with this analysis the relationship (coupling) between occupied insulin receptors and glucose transport is only impeded by more than $24 \mathrm{~h}$ of fasting. These findings are further quantitated in Table IV, which gives the number of insulin molecules that must bind to cells from fasting and control animals to achieve a half-maximal effect on 2-deoxy-glucose uptake. 48 and $72 \mathrm{~h}$ of fasting leads to an 87 and $112 \%$ increase in the amount of insulin that must be bound to half-maximally stimulate uptake, whereas the amount bound to achieve half-maximal stimulation is comparable for cells from control and 24-h-fasted animals.

Effects of a milder degree of caloric deprivation. Fasting is a rather drastic state of negative caloric balance, which thus can only be carried out for relatively brief periods $(72 \mathrm{~h})$, and affects both insulin binding and glucose transport. As suggested by the data from the 24-h-fasted animals, it seemed possible that milder but more prolonged caloric deprivation might elicit subtler changes in the insulin receptor-effector system, and might lead to changes in either insulin receptors or glucose transport systems alone. Thus, a group of rats were maintained on an average of $12 \mathrm{~g}$ of food/day ${ }^{4}$ for 7 days, to achieve a slight but more chronic degree of weight loss. Mean body weight of these animals decreased from $194 \pm 3 \mathrm{~g}$ to $184 \pm 2 \mathrm{~g}$ over the 7 days. Insulin binding increased by $35 \%$, the $V_{\max }$ of 2-deoxy-glucose uptake decreased by $20 \%$, and the shape of the insulin-2deoxy-glucose uptake dose response curves demonstrated a left shift (data not shown) analogous to the data from the 24-h-fasted rats (Figs. 8 and 10). Thus again, when insulin binding increases but the glucose transport system remains reasonably intact, a left shift in the insulin dose-response curve can be demonstrated.

${ }^{4}$ Normally these animals will consume $23 \mathrm{~g}$ of food/day
on ad lib feedings and would gain $25-35 \mathrm{~g}$ of body weight. 


\section{DISCUSSION}

These studies have shown that fasting is associated with an increase in insulin binding to isolated rat adipocytes. Furthermore, fasting is associated with a progressive decrease in basal and insulin-stimulated rates of 2-deoxy-glucose uptake, and the magnitude of this decrease is closely correlated with the degree of negative caloric balance. Given these opposite effects on insulin binding and glucose transport, the relationship between insulin binding to receptors and insulin's effect on glucose metabolism is complex. This relationship is further complicated by the fact that maximal insulin effects on glucose transport and oxidation are seen when only a minority (10-18\%) of insulin receptors are occupied. Thus, adipocytes have "spare" receptors, and if the effector systems are intact, then a decrease in insulin binding will lead to a rightward shift in the insulin dose-response curve $(9,30)$, and an increase in binding should lead to a leftward shift.

Since the effector systems for glucose metabolism are not intact in fasting, the interpretation of the relationship between insulin binding and insulin-stimulated glucose metabolism is difficult. For example, that insulin binding increases while maximal insulinstimulated rates of glucose oxidation decrease may appear somewhat paradoxical at first glance. However, fasting leads to a decrease in glucose transport (effector) activity, and furthermore, when the effects of fasting on glucose oxidation and transport are compared, it is clear that oxidation is decreased more than transport. This indicates that all of the decrease in glucose oxidation cannot be accounted for by decreases in glucose transport, and, therefore, fasting must exert some inhibiting effect on intracellular glucose oxidation. Thus, in absolute terms there is a greater impediment in coupling between insulin receptors and glucose oxidation than between receptors and glucose transport. Although the latter is still clearly impeded, the defect is least in the 24-hfasted animals.

On the other hand, the overall capacity of the glucose transport system is decreased during fasting, as indicated by the decrease of $V_{\max }$ in both the basal and insulin-stimulated state. Therefore, during fasting, insulin (or other glucose transport stimulants) cannot increase transport to the same absolute rates observed in control cells, and this is probably a function of the decrease in glucose transport system capacity rather than a function of the interaction between insulin receptors and glucose transport structures. Thus, it seems reasonable to suggest that a method of analysis that accounts for these differences in transport capacity might reveal greater insights into the relationship between insulin receptors and glucose transport. Such a method is provided in Fig. 9B, in which the transport data are calculated as percent effect rather than as absolute values (the validity of this approach is also suggested by the high correlation $[r=0.85]$ between basal and insulin stimulated rates of 2-deoxy-glucose uptake). This analysis is consistent with a model that assumes that the ability of a single unstimulated glucose transport unit to respond to an occupied insulin receptor(s) is independent of the number of, or state of activity of, the remaining membrane glucose transport structures. Such a model fits previous data relating insulin binding and glucose transport in both dexamethasone-treated adipocytes (6) and large adipocytes from old obese rats (9). With this form of analysis, the cells from the 24-h-fasted rats demonstrate a left shift in the insulin dose-response curve, and, although control cells require a higher medium insulin concentration to give equivalent binding, the same amount of insulin bound will give the same percentage insulin effect in cells from control and 24-h-fasted rats. In this sense, $24 \mathrm{~h}$ of fasting increases insulin binding without changing coupling between occupied receptors and glucose transport, and insulin sensitivity is enhanced. However, $48-72 \mathrm{~h}$ of fasting leads to a further increase in insulin binding (at insulin concentrations less than $5 \mathrm{ng} / \mathrm{ml}$ ) but no shift in the insulinglucose transport response curve. Consequently, these cells must bind twice as much insulin to achieve the same insulin effect. Thus, the relationship between occupied insulin receptors and glucose transport is altered, and coupling is impeded by 48 and $72 \mathrm{~h}$ of fasting. These findings are supported by the data obtained from the milder, more chronically weightreduced rats. In these animals insulin binding increased, but the glucose transport system was left reasonably intact, and the insulin dose-response curve shifted leftwards. Thus, when a milder degree of caloric deprivation is imposed, adipocytes respond with an increase in insulin binding, a decrease in glucose transport capacity, no alteration in coupling between receptors and transport, and, therefore, enhanced insulin sensitivity (greater effect at lower media insulin concentrations). When caloric deprivation becomes more severe, insulin binding continues to increase, transport capacity declines further, and coupling between occupied receptors and the glucose transport system is impeded. However, at $48-72 \mathrm{~h}$ of fasting the increase in insulin binding and decrease in coupling essentially counterbalance each other, and insulin sensitivity remains equal to controls (equal insulin effects at the same concentration).

During fasting, the $K_{m}$ of the 2-deoxy-glucose uptake system remains unchanged while $V_{\max }$ decreases. This suggests that the affinity of the transport system for 
glucose is not altered, while the maximal capacity decreases, and is consistent with the formulation that fasting leads to a decrease in the number of active or available transport sites. These data also indicate that insulin promotes glucose transport by increasing $V_{\max }$ without changing $K_{m}$. Whether this latter effect involves an increase in the number of available transport sites and/or an increase in the activity of the existing sites remains to be determined.

Bar et al. (31) have recently studied insulin binding to circulating monocytes from fasting man and have observed a marked increase in receptor affinity with no change in receptor number. Obviously, these results are in good agreement with the findings of these current studies. However, the changes in insulin binding observed in fasting are unusual. Most reported changes in insulin binding have involved changes in the number of insulin receptors per cell without any alterations in the affinity of the receptor for insulin. Cells from fasting animals bind more insulin than control cells at lower insulin concentrations $^{5}$ but bind comparable amounts at higher, saturating insulin levels. Thus, the affinity of the receptor for insulin is increased. DeMeyts et al. (24) have demonstrated site-site interactions of the negative cooperative type between insulin receptor sites. When the binding data are analyzed according to their methods (32), fasting is associated with a greater limiting high affinity for binding, a higher average affinity (at insulin concentrations less than $25 \mathrm{ng} / \mathrm{ml}$ ), and an increase in the fractional occupancy of sites needed to reach a limiting lower affinity (i.e. when negative cooperative effects are maximal). The fractional occupancy at which site-site interactions begin cannot be determined by the current data. Thus, during fasting, insulin receptors apparently undergo a conformation change such that their affinity in the native, or high-affinity configuration, increases, and the degree of site-site interaction decreases (in the sense that a greater proportion of the receptors must be occupied to exert the maximal cooperative effect). The exact nature of this increase in binding affinity is not clear at this time, but it is possible that this represents a regulatory mechanism whereby some metabolic change during fasting leads to a change in receptor affinity.

\section{ACKNOWLEDGMENT}

The author wishes to thank Mrs. Helen Chang and Ms. Christine Feliton for their expert technical work.

This work was supported by the Medical Research Service of the Veterans Administration and by a grant from the National Institutes of Health (HL08506).

\footnotetext{
5 It should be noted, that "lower" insulin concentrations includes the entire range of physiologic circulating insulin levels.
}

\section{REFERENCES}

1. Ensinck, J. W., and R. H. Williams. 1974. Disorders causing hypoglycemia. In Williams Textbook of Endocrinology. R. H. Williams, editor. W. B. Saunders Company, Philadelphia, Pa. 5th edition. 627-659.

2. Cahill, G. F., Jr., M. G. Herrera, A. P. Morgan, J. S. Soeldner, J. Steinke, P. L. Levy, G. A. Reichard, Jr., and D. M. Kipnis. 1966. Hormone-fuel interrelationships during fasting. J. Clin. Invest. 45: 1751-1769.

3. Di Girolamo, M., and D. Rudman. 1968. Variations in glucose metabolism and sensitivity to insulin of the rat's adipose tissue, in relation to age and body weight. Endocrinology. 82: 1133-1141.

4. Olefsky, J. M., and G. M. Reaven. 1975. Effects of age and obesity on insulin binding to isolated adipocytes. Endocrinology. 96: 1486-1490.

5. Soll, A. H., I. D. Goldfine, J. Roth, C. R. Kahn, and D. M. Neville, Jr. 1974. Thymic lymphocytes in obese (oblob) mice. A mirror of the insulin receptor defect in liver and fat. J. Biol. Chem. 249: 4127-4131.

6. Olefsky, J. M. 1975. Effect of dexamethasone on insulin binding, glucose transport, and glucose oxidation by isolated rat adipocytes. J. Clin. Invest. 56: 1499-1508.

7. Kono, T., and F. W. Barham. 1971. The relationship between the insulin-binding capacity of fat cells and the cellular response to insulin. Studies with intact and trypsin-treated fat cells. J. Biol. Chem. 246: 62106216.

8. Gammeltoft, S., and J. Gliemann. 1973. Binding and degradation of ${ }^{125}$ I-labelled insulin by isolated rat fat cells. Biochim. Biophys. Acta. 320: 16-32.

9. Olefsky, J. M. 1976. The effects of spontaneous obesity on insulin binding, glucose transport, and glucose oxidation of isolated rat adipocytes. J. Clin. Invest. 57: 842-851.

10. Rodbell, M. 1964. Metabolism of isolated fat cells. I. Effects of hormones on glucose metabolism and lipolysis. J. Biol. Chem. 239: 375-380.

11. Hirsch, J., and E. Gallian. 1968. Methods for the determination of adipose cell size in man and animals. J. Lipid Res. 9: 110-119.

12. Di Girolamo, M., S. Medlinger, and J. W. Fertig. 1971. A simple method to determine fat cell size and number in four mammalian species. Am. J. Physiol. 221: 850858.

13. Freychet, P., J. Roth, and D. M. Neville, Jr. 1971. Monoiodoinsulin: demonstration of its biological activity and binding to fat cells and liver membranes. Biochem. Biophys. Res. Commun. 43: 400-408.

14. Hunter, W. M., and F. C. Greenwood. 1962. Preparation of iodine-131 labelled human growth hormone of high specific activity. Nature. (Lond.). 194: 495-496.

15. Olefsky, J. M., and G. M. Reaven. 1974. The human lymphocyte: a model for the study of insulin-receptor interaction. J. Clin. Endocrinol. Metab. 38: 554-560.

16. Gavin, J. R., III, P. Gorden, J. Roth, J. A. Archer, and D. N. Buell. 1973. Characteristics of the human lymphocyte insulin receptor. J. Biol. Chem. 248: 2202-2207.

17. Olefsky, J. M., J. Johnson, F. Liu, P. Jen, and G. M. Reaven. 1975. The effects of acute and chronic dexamethasone administration on insulin binding to isolated rat hepatocytes and adipocytes. Metab. Clin. Exp. 24: 517-527.

18. Olefsky, J. M., P. Jen, and G. M. Reaven. 1974. Insulin binding to isolated human adipocytes. Diabetes. 23: $565-571$. 
19. Wick, A. N., D. R. Drury, H. I. Hakada, and J. B. Wolfe. 1957. Localization of the primary metabolic block produced by 2-deoxyglucose. J. Biol. Chem. 224: 963-969.

20. Gliemann, J., K. Osterlind, J. Vinten, and S. Gammeltoft. 1972. A procedure for measurement of distribution spaces in isolated fat cells. Biochim. Biophys. Acta. 286: $1-9$.

21. Desbuquois, B., and G. D. Aurbach. 1971. Use of polyethylene glycol to separate free and antibody-bound peptide hormones in radioimmunoassays. J. Clin. Endocrinol. Metab. 33: 732-738.

22. Scatchard, G. 1949. The attractions of proteins for small molecules and ions. Ann. N. Y. Acad. Sci. 51: 660-672.

23. Kahn, C. R., P. Freychet, J. Roth, and D. M. Neville, Jr. 1974. Quantitative aspects of the insulin-receptor interaction in liver plasma membranes. J. Biol. Chem. 249: 2249-2257.

24. De Meyts, P., J. Roth, D. M. Neville, Jr., J. R. Gavin, III, and M. A. Lesniak. 1973. Insulin interactions with its receptors: experimental evidence for negative cooperativity. Biochem. Biophys. Res. Commun. 55: 154-161.

25. Renner, E. D., P. G. W. Plagemann, and R. W. Bernlohr. 1972. Permeation of glucose by simple and facilitated diffusion by Novikoff rat hepatoma cells in suspension culture and its relationship to glucose metabolism. J. Biol. Chem. 247: 5765-5776.

26. Kletzien, R. F., and J. F. Perdue. 1974. Sugar transport in chick embryo fibroblasts. I. A functional change in the plasma membrane associated with the rate of cell growth. J. Biol. Chem. 249: 3366-3374.

27. Czech, M. P., J. C. Lawrence, Jr., and W. S. Lynn 1974. Hexose transport in isolated brown fat cells. A model system for investigating insulin action on membrane transport. J. Biol. Chem. 249: 5421-5427.

28. Weber, M. J. 1973. Hexose transport in normal and in Rous sarcoma virus-transformed cells. J. Biol. Chem. 248: 2978-2983

29. Hatanaka, M. 1974. Transport of sugars in tumor cell membranes. Biochim. Biophys. Acta. 355: 77-104.

30. Freychet, P. 1976. Interactions of polypeptide hormones with cell membrane specific receptors: studies with insulin and glucagon. Diabetologia. 12: 83-100.

31. Bar, R. S., P. Gorden, J. Roth, C. R. Kahn, and P. De Meyts. 1976. Regulation of the affinity and concentration of insulin receptors in man. Clin. Res. 34: 269A (Abstr.).

32. De Meyts, P., and J. Roth. 1975. Cooperativity in ligand binding: a new graphic analysis. Biochem. Biophys. Res. Commun. 66: 1118-1126. 